\title{
Long-toed Salamander (Ambystoma macrodactylum) hibernacula in Waterton Lakes National Park revealed using Passive Integrated Transponder telemetry
}

\author{
Matthew R. Atkinson-Adams ${ }^{1}$, Christopher J. Price ${ }^{1}$, Garry J. Scrimgeour ${ }^{2}$, and Cynthia \\ A. Paszkowski ${ }^{1, *}$

\begin{abstract}
${ }^{1}$ Department of Biological Sciences, University of Alberta, 116 Street - 85 Avenue, Edmonton, Alberta T6G 2E9 Canada
${ }^{2}$ Environment and Parks, Government of Alberta, 9920 - 108th Street, Edmonton, Alberta T5J 5C6 Canada

*Corresponding author: cindy.paszkowski@ualberta.ca
\end{abstract}

Atkinson-Adams, M.R., C.J. Price, G.J. Scrimgeour, and C.A. Paszkowski. 2018. Long-toed Salamander (Ambystoma macrodactylum) hibernacula in Waterton Lakes National Park revealed using Passive Integrated Transponder telemetry. Canadian Field-Naturalist 132(2): 168-175. https://doi.org/10.22621/cfn.v132i2.2056

\begin{abstract}
Long-toed Salamanders (Ambystoma macrodactylum) spend most of their lives on land; however, their fossorial nature makes studying their use of habitat difficult. Using Passive Integrated Transponder (PIT) telemetry over two years, we found and characterized nine overwintering sites of Long-toed Salamanders in the vicinity of Linnet Lake and Stable Pond in Waterton Lakes National Park, excavating five of them. These sites were typically associated with stumps and decaying root systems that gave the salamanders access to deep subterranean hibernacula. Overwintering sites were located up to $168 \mathrm{~m}$ from the shores of breeding ponds. Given the importance of such terrestrial sites to these populations of Long-toed Salamanders, it is vital that conservation efforts include the preservation of these features and ensure that a sufficient area surrounding breeding ponds remains undisturbed.
\end{abstract}

Key words: Long-toed Salamander; Ambystoma macrodactylum; amphibian; terrestrial habitat; conservation; overwintering refugia; Waterton Lakes National Park; Alberta

\section{Introduction}

Long-toed Salamander (Ambystoma macrodactylum) is a widespread, relatively common species of "mole salamander" (Ambystomatidae) of western North America, whose Canadian range includes portions of British Columbia and Alberta (Petranka 1998; Lee-Yaw and Irwin 2012). In Alberta, it is patchily distributed, mainly along the east slopes of the Rocky Mountains, defining the northeastern edge of the species' global range. Isolated Alberta populations occur near Fairview in the north and Stavely in the south (Russell and Bauer 2000).

Provincially, Long-toed Salamander is listed as a species of special concern (Alberta Environment and Parks 2014). Although Alberta's populations of the Long-toed Salamander currently appear stable, a number of threats have been identified. These include energy sector and forestry activity, urbanization, fish stocking, and the widespread construction of roads near breeding ponds (Graham and Powell 1999).

Long-toed Salamanders in Alberta breed mainly in shallow, productive, fish-free ponds and lakes in a variety of landscape types (Graham and Powell 1999; Pearson 2004). Adults enter breeding ponds at ice-off and leave by early summer, whereas larvae metamorphose and leave ponds in late summer and early fall (Graham and Powell 1999). Use of the terrestrial environment by juveniles and adults has been more diffi- cult to document because of the subterranean habits of the species. During the active season, Long-toed Salamanders, like other mole salamanders, are typically found in the leaf litter and emerge on moist nights to forage for invertebrate prey. In Alberta, they occupy home ranges of $115-280 \mathrm{~m}^{2}$ and can travel up to $900 \mathrm{~m}$ from breeding ponds to reach these sites (Sheppard 1977; Graham 1997).

Little is known about the species' overwintering locations. In the single study exploring this aspect of habitat use in Alberta, Sheppard (1977) employed radioactive marking to locate three Long-toed Salamander hibernacula in the Bow Valley. Information on overwintering behaviour can be critical for the conservation of northern amphibian populations, where the existence of appropriate hibernation sites, near breeding ponds and foraging habitat, may dictate the size, distribution, and persistence of populations (Browne and Paszkowski 2010).

Fine-scale patterns of terrestrial habitat use are often difficult to document for amphibians at any time of year, because of their small body size and cryptic nature. Technical limitations come into play when applying tracking devices to small-bodied vertebrates, either internally or externally, and transmitters can affect behaviour and survivorship (Weatherhead and BlouinDemers 2004; Barron et al. 2010). However, radiofrequency identification (RFID) and Passive Integrated 
Transponder (PIT) technologies provide a convenient method for investigating habitat use and movement patterns of small species, including amphibians (Cucherousset et al. 2008; Hamed et al. 2008; Connette and Semlitsch 2012; Ryan et al. 2014). PIT tags and "PIT telemetry" can liberate investigators from the size constraints and battery-life limitations of conventional radio telemetry.

We used this technology to study a population of Long-toed Salamanders in Waterton Lakes National Park in southwestern Alberta. The Long-toed Salamanders breeding in Linnet Lake and nearby Stable Pond have been the subject of research since the 1990s, in part because of mortality of migrating salamanders on the adjacent Entrance Road (Fukumoto and Herrero 1998). In 2008, four tunnels under Entrance Road were installed to reduce roadkill at Linnet Lake (Pagnucco et al. 2012). We captured Long-toed Salamanders at Linnet Lake (2013, 2014) and Stable Pond (2014) and PIT tagged them. At Linnet Lake our fundamental objective was to assess tunnel use with stationary RFID antennae as animals moved to and from this breeding site (Atkinson-Adams 2015). In addition, we used PIT telemetry to investigate the use of terrestrial habitat surrounding breeding sites during the summer and fall of 2013 (Linnet Lake) and 2014 (Stable Pond). One goal of these surveys was to locate Long-toed Salamander hibernation sites and characterize their

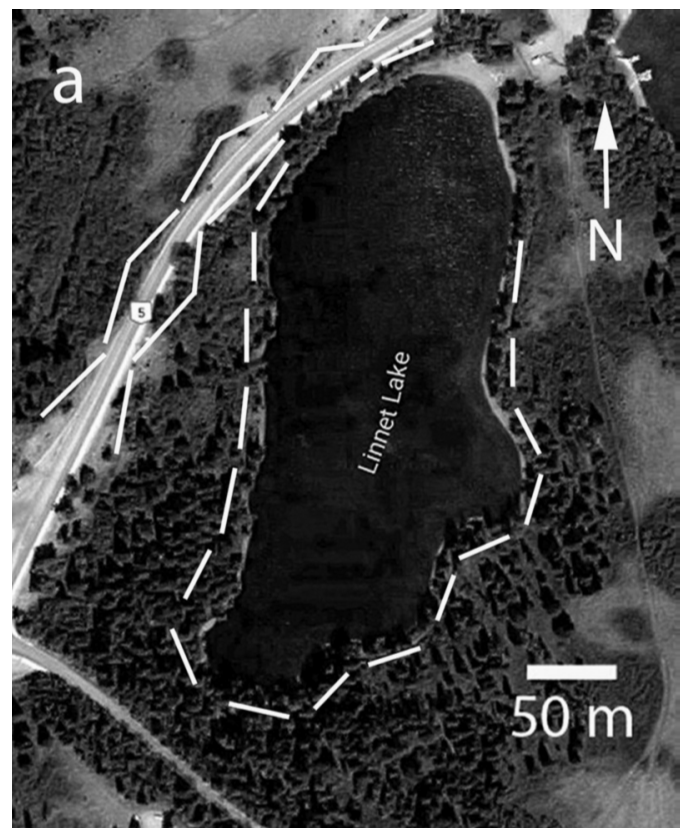

above- and below-ground features. We postulated that one reason that Long-toed Salamanders crossed Entrance Road was to move between aquatic breeding sites and specific terrestrial macro- or micro-habitats required for overwintering.

\section{Study Area}

Research centred on two breeding sites in Waterton Lakes National Park, Alberta: Linnet Lake (in 2013 and 2014) and Stable Pond (in 2014; Figure 1). Linnet Lake $\left(49.07^{\circ} \mathrm{N}, 113.9^{\circ} \mathrm{W}\right)$ is a small (3.9 ha), shallow ( $5 \mathrm{~m}$ maximum depth) lake at an elevation of $\sim 1260 \mathrm{~m}$ in a bowl-like catchment basin. The vegetation around the lake is dominated by stands of Douglas Fir (Pseudotsuga menziesii (Mirbel) Franco) and poplar (Populus spp.), with an understorey of small trees and shrubs, such as Chokecherry (Prunus virginiana L.), Saskatoon (Amelanchier alnifolia (Nuttall) Nuttall ex M. Roemer), and Snowberry (Symphoricarpos albus (L.) S.F. Blake). The lake is surrounded by a moderately steep hillside (slope up to $15 \%$ ) except on the north end, which is a flat, low-lying area adjacent to Middle Waterton Lake. The park's Entrance Road runs along the west side of the lake at a straight-line distance of 13-110 m. The stretch of this road bordering the lake is punctuated by four salamander tunnels spaced $\sim 80-110 \mathrm{~m}$ apart (described in detail by Pagnucco et al. 2012). Linnet Lake is inhabited by three fish species: White Sucker

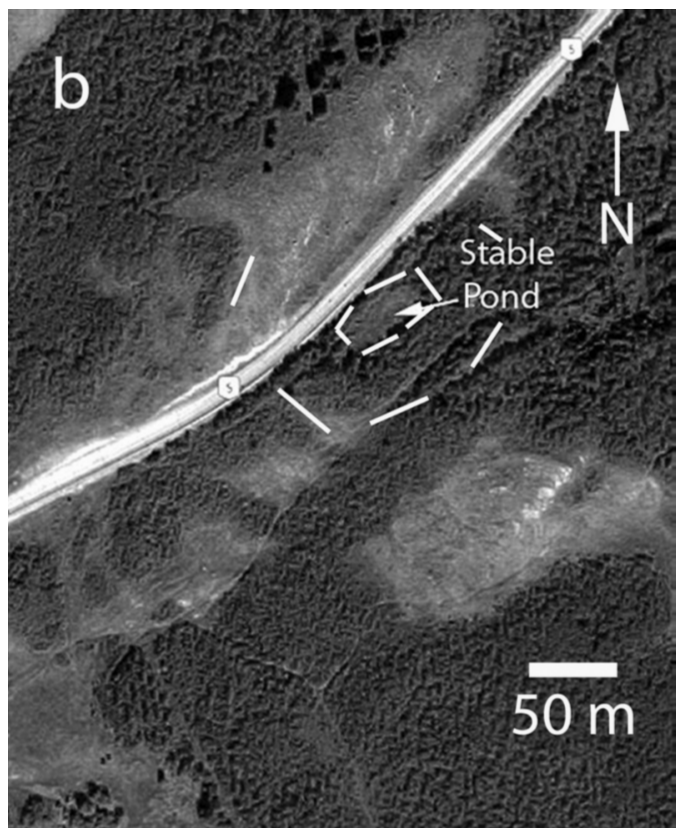

Figure 1. Images of the two study sites in Waterton Lakes National Park, Alberta. a. Linnet Lake. b. Stable Pond, which is $1.2 \mathrm{~km}$ northeast of Linnet Lake. Entrance Road (Highway 5) runs west of each water body. The approximate location of our drift fences and, in the case of Linnet Lake, permanent fencing along Entrance Road are indicated by white lines. Source: Linnet Lake, $49.07^{\circ} \mathrm{N}, 113.9^{\circ} \mathrm{W}$; Stable Pond, $49.07^{\circ} \mathrm{N}, 113.88^{\circ} \mathrm{W}$. Data provider: Imagery, DigitalGlobe (2017); Map data, Google Canada (2017). Date Accessed: 1 May 2018. 
(Catostomus commersonii), Longnose Sucker (Catostomus catostomus), and Lake Chub (Couesius plumbeus). Western Toads (Anaxyrus boreas) and Western Tiger Salamanders (Ambystoma mavortium) are also found on site.

Stable Pond $\left(49.07^{\circ} \mathrm{N}, 113.88^{\circ} \mathrm{W}\right)$ is a small $(0.15$ ha), fishless pond $1.2 \mathrm{~km}$ to the northeast of Linnet Lake, at an elevation of $1275 \mathrm{~m}$. With a maximum depth of $1.6 \mathrm{~m}$, it typically dries up by midsummer (22 July in 2013, 7 August in 2014) to become a grassdominated meadow. Stable Pond is surrounded by poplar forest and flat terrain that breaks into open grass and low shrubs to the south and poplar forest with isolated stands of Douglas Fir to the east. To the west, the pond is immediately bordered by Entrance Road. Western Toads and Boreal Chorus Frogs (Pseudacris maculata) also breed in Stable Pond.

\section{Methods}

\section{Salamander capture}

To capture salamanders at Linnet Lake, a series of 16 (2013) or eight (2014) 30-m drift fences (silt fencing, $1 \mathrm{~m}$ high) were installed $10-25 \mathrm{~m}$ from the lake to create temporary barriers to salamander movement; no pitfall traps were employed here (Atkinson-Adams 2015). In addition, four permanent fences (corrugated plastic, $45 \mathrm{~cm}$ high) designed to keep salamanders off the road and to funnel them into the under-road tunnels were present on both sides of Entrance Road, each varying in length from $40 \mathrm{~m}$ to $123 \mathrm{~m}$. Fences were walked nightly beginning on 25 April in 2013 and on 17 April in 2014; all salamanders were captured and held for identification or marking (see below). Nightly searches continued until five consecutive nights passed with no salamander encounters, which occurred in late June in both years. Searches were re-initiated on the next rainy night and continued nightly until no salamanders were encountered (8 July in 2013 and 2 July in 2014). Salamanders were also opportunistically caught around Linnet Lake and on Entrance Road.

In 2014, drift fences (silt fencing, $1 \mathrm{~m}$ high) were installed to capture salamanders at Stable Pond: a series of five $30-\mathrm{m}$ fences, $3 \mathrm{~m}$ from the high waterline and five $30-\mathrm{m}$ fences, $50 \mathrm{~m}$ from the high waterline (Atkinson-Adams 2015). Fifty pitfall traps, made from \#10 food service cans $(15.9 \mathrm{~cm}$ in diameter, $17.8 \mathrm{~cm}$ deep), were buried either along both sides of fences (April-June) or only along the pond side of fences (July-August) to capture young-of-the year (YOY). Ten minnow-traps $(42 \mathrm{~cm} \times 19 \mathrm{~cm}, 6.4-\mathrm{mm}$ mesh, 2.5cm openings) were placed in the pond, evenly spaced around the perimeter, to trap breeding adults. Traps were checked daily, usually within $1 \mathrm{~h}$ of sunrise. Handling of captured salamanders was the same as described above for Linnet Lake.

\section{Salamander marking}

Captured salamanders from a single fence or trap were placed individually on moist paper towelling in a site-labelled plastic container and transported to an indoor laboratory for marking and identification. Recaptured, PIT-tagged salamanders were individually identified with a hand-held half-duplex (HDX) proximity reader (Datamars, Lamone, Switzerland). Unmarked juvenile and adult salamanders were anaesthetized by immersion in $1 \mathrm{~g} / \mathrm{L}$ trimethane sulfonate solution until unresponsive to prodding (typically 610 minutes). Salamanders with swollen vents (could be sexed) were considered mature adults, and smaller salamanders without swollen vents (could not be sexed) were considered juveniles. Juvenile salamanders captured at Stable Pond in July and, later, those bearing gill remnants behind the jaw were considered YOY. No YOY were seen at Linnet Lake.

PIT tagging involved the insertion of a $12 \mathrm{~mm} \times$ $2.12 \mathrm{~mm}$ sterile HDX PIT tag (Texas Instruments, Dallas Texas, USA) weighing $0.1 \mathrm{~g}(10 \%$ of body weight maximum, typically $<2 \%$ ) into the body cavity via a 3-mm incision made using a fresh \#11 scalpel blade just anterior to the right hind leg and slightly toward the midline. The incision was closed with Vetbond Tissue Adhesive (3M, St. Paul, Minnesota, USA), which was applied to the dried incision while holding the opposing edges of the incision together with forceps. Consistent with other studies on urodeles, PIT-tag implantation had no apparent short-term effects on salamander behaviour or survival (e.g., Ott and Scott 1999). PIT-tagged animals were also marked either by clipping the second phalangeal joint on toe three of the right hind leg or through injection of red or orange visual implant elastomer (Northwest Marine Technologies, Shaw Island, Washington, USA) subdermally at the ventral base of the tail just posterior to the vent. After wound closure, salamanders were placed in a container of non-chlorinated water shallow enough to allow their heads to remain above water until they recovered from anaesthesia (typically 10-15 minutes). Once recovered (moving, responsive to prodding), individuals were placed in their original containers and released within $3 \mathrm{~h}$ near the point of capture.

\section{Using PIT telemetry to locate overwintering salamanders}

We began using PIT telemetry to search the terrestrial environment for tagged salamanders after peak migration of adults from breeding sites (4 June 2013 at Linnet Lake and 9 June 2014 at Stable Pond). Scanning was performed to document movement patterns and habitat use by adults and juveniles in summer (not reported here, see Atkinson-Adams 2015) and to identify locations to survey for hibernating salamander in fall. In both years, scanning was initiated near the shoreline, working outward to areas $\sim 200 \mathrm{~m}$ from shore in a series of rectangular transects during the summer season, ending on 29 August in both years. We scanned $98850 \mathrm{~m}^{2}$ at Linnet Lake and $51450 \mathrm{~m}^{2}$ at Stable Pond following methods described in Kuhnz (2000). 
Walking in straight-line transects, we brought a handmade RFID scanner as close as possible to the ground and swept side-to-side (see Atkinson-Adams et al. 2016). Transects were $30 \mathrm{~m}$ long with overlap between adjacent transects to minimize unscanned terrain. The scanner was a wand-like portable RFID antenna used in conjunction with a tuning capacitor and HDX backpack reader (Oregon RFID, Portland, Oregon, USA) set to scan five times per second. The portable RFID antenna consisted of a 61-cm diameter antenna loop encased in sturdy plastic tubing attached to a length of polyvinyl chloride tubing (length $\sim 2 \mathrm{~m}$, diameter $3.2 \mathrm{~cm}$ ). Systematic testing indicated a maximum vertical detection depth of $\sim 72 \mathrm{~cm}$ in soil or rocky substrates with the scanner placed directly on the ground (Atkinson-Adams et al. 2016), which is comparable to the depths at which Sheppard (1977) found overwintering Long-toed Salamanders using radioactive tracers.

We scanned for overwintering Long-toed Salamanders 3-15 October 2013 at Linnet Lake and 15-23 November 2014 at Stable Pond. Based on values reported by Sheppard (1977), we assumed that adults had summer home ranges averaging $150 \mathrm{~m}^{2}$, and that overwintering sites would be located within or near these home ranges. Thus, we returned to the location of the most recently detected individuals from summer scanning efforts (e.g., 28 August 2013 and 26 August 2014) and scanned a $30 \mathrm{~m} \times 30 \mathrm{~m}\left(900 \mathrm{~m}^{2}\right)$ plot orientated northsouth and centred on the August location using the transect-scanning methods described above. In addition to scanning at known late-summer locations, we sampled a previously unscanned area across (west of) Entrance Road at Linnet Lake in 2013 and the dried bottom of Stable Pond in 2014.

\section{Characterization of overwintering sites}

When a salamander was detected during searches for overwintering sites, its location was marked and then returned to for investigation after the $30 \mathrm{~m} \times 30 \mathrm{~m}$ plot was scanned completely. If multiple salamanders were detected in the same plot, sites were examined in the order in which they were found.

To characterize overwintering sites, aboveground features were recorded: dominant vegetation, light level, percentage cover, and number and type of aboveground objects. Then, an attempt was made to excavate the salamander to describe the underground hibernaculum and to see if other individuals were present. Light levels were measured as per cent transmittance (footcandles) using a light meter (Model 217, General Electric, Boston Massachusetts, USA). Estimated per cent cover within a 1-m-diameter circular plot, centred on the site, were recorded: leaf litter, grass/forb, woody vegetation, small $(<10 \mathrm{~cm}$ diameter) and large $(\geq 10 \mathrm{~cm}$ diameter) woody debris, rock, moss, and bare ground. The number and type of aboveground objects - small (1.5$10 \mathrm{~cm}$ diameter) and large ( $\geq 10 \mathrm{~cm}$ diameter) trees, wood (bark, logs, or stumps), rocks $\geq 10 \mathrm{~cm}$ wide — and the presence of mammal burrows were determined within a 2-m radius of the relocation site. After it was characterized, we carefully excavated the site with a spade until either the salamander was located with a hand-held HDX proximity reader (maximum read range $\sim 12 \mathrm{~cm}$ ) or it was determined that alterations caused by further digging would be too extensive to repair. Excavations were then returned as nearly as possible to their original state, including returning aboveand below-ground material and re-establishing tunnels and air spaces to allow the replaced salamanders to emerge in the spring.

\section{Results}

PIT telemetry yielded reasonable rates of relocation for tagged Long-toed Salamanders using our handmade RFID scanner (Atkinson-Adams et al. 2016) to survey terrestrial habitat. In summer, 32 of 404 tagged Linnet Lake salamanders (2013) and 82 of 629 tagged Stable Pond salamanders (2014) were detected in 81 and 83 days of scanning, respectively. The area surrounding both breeding sites was heavily vegetated and uneven, with scattered large rocks and woody debris, which limited the number of detections (AtkinsonAdams et al. 2016). We found little evidence that PIT tags were readily lost or were the cause of substantial mortality. Summer scanning uncovered five "naked" PIT-tags on or near the soil surface at Linnet Lake and 22 at Stable Pond, representing 2\% and 9\% of implanted tags, respectively. Tags may have been shed by living animals (Ott and Scott 1999) or may represent disintegrated carcasses of dead animals. At Stable Pond, we located intact carcasses of two salamanders that still contained PIT tags. Our surveys in October and November succeeded in uncovering hibernating sites. We located seven salamanders in fall 2013 (all with PIT tags) and nine salamanders in fall 2014 (seven with PIT tags, plus two additional individuals without tags cooccurring with tagged salamanders).

In October 2013, during 13 days of scanning at Linnet Lake, we sampled 14, $30 \mathrm{~m} \times 30 \mathrm{~m}$ plots based on old locations and $12500 \mathrm{~m}^{2}$ of new area on the far side of Entrance Road. Seven salamanders were detected: one was $87 \mathrm{~m}$ west of Entrance Road, the others were east of the road (Figure 1). Three of the seven salamanders were located on the soil surface, $<5 \mathrm{~cm}$ deep in the leaf litter, $74 \mathrm{~m}, 127 \mathrm{~m}$, and $143 \mathrm{~m}$ from the shoreline of Linnet Lake. When revisited on 15 October, after a spell of warm weather (day-time high of $12^{\circ} \mathrm{C}$ ), these three individuals were gone; thus, these locations were not considered to be hibernation sites and are not described in Table 1. A different individual was detected at one of these locations on 12 April 2014 (under 10-20 cm snow) and 19 April (no snow), but was absent in May, only to be detected again on 16 November 2014. Three of the salamanders had been previously relocated following PIT tagging and were $15 \mathrm{~m}, 19 \mathrm{~m}$, and $134 \mathrm{~m}$ from the earlier locations. 
Vol. 132

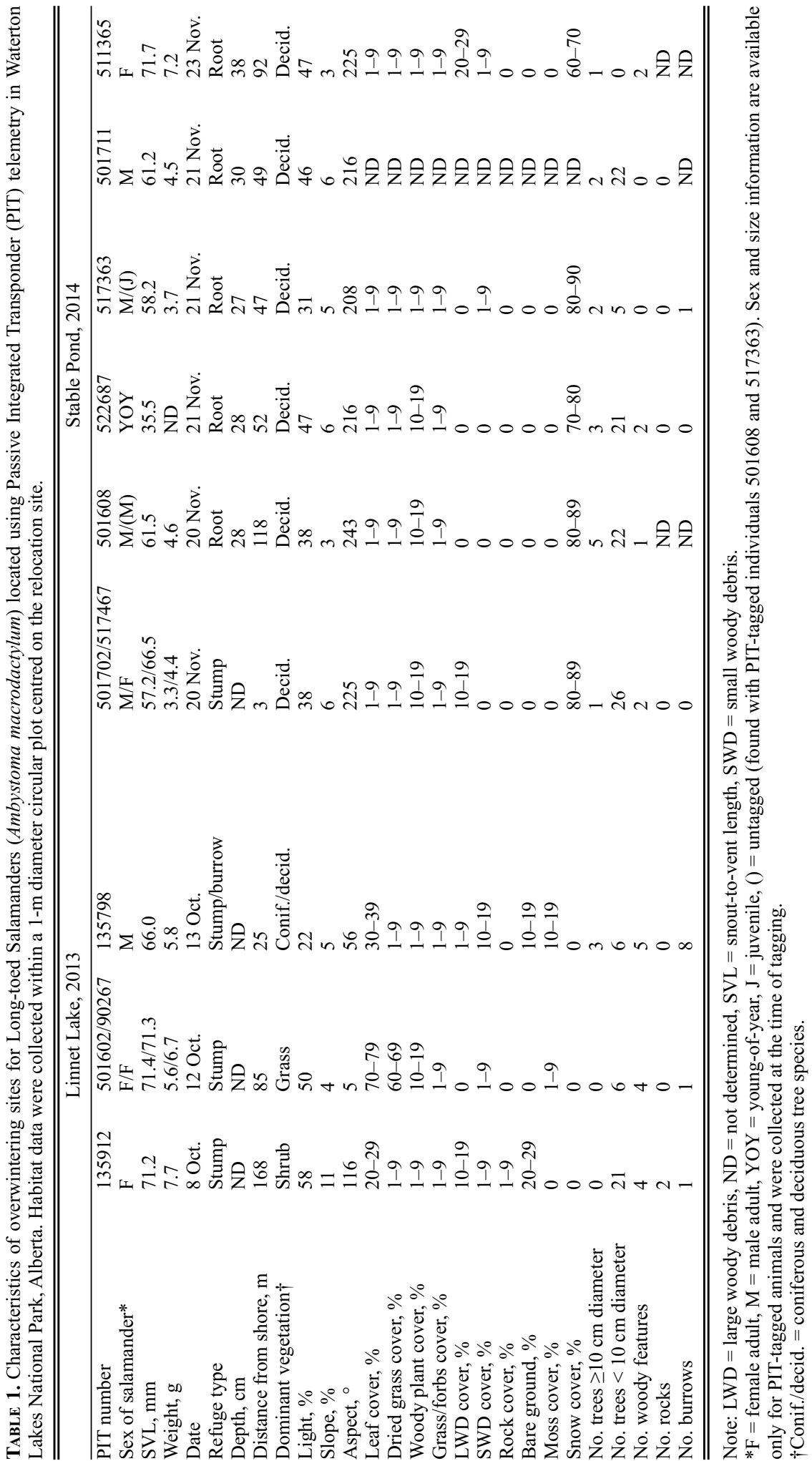


For the three apparent hibernation sites at Linnet Lake, it was not possible to excavate salamanders to determine actual depth, precise refuge type, or presence of other occupants. All three locations, one of which contained two PIT tagged individuals, were within $2 \mathrm{~m}$ of old rotten stumps of coniferous or deciduous trees and were at estimated depths $>25 \mathrm{~cm}$ based on adjacent excavations and combined readings from our custommade RFID scanner and a hand-held HDX proximity reader (maximum read range $\sim 12 \mathrm{~cm}$ ). Three salamanders appeared to be in the matrix of decomposed roots associated with the stump itself and one appeared to be within a network of small mammal tunnels in the slope immediately below the stump, which, based on the presence of cone scales, were likely used by Red Squirrels (Tamiasciurus hudsonicus). Sites were 25-168 m from the shoreline of Linnet Lake. We found no pattern in vegetation cover or larger-scale characteristics of overwintering sites (Table 1). The dominant vegetation varied among sites and was deciduous trees, a mix of coniferous and deciduous trees, shrubs, or grass. Detailed characteristics of the sites are presented in Table 1.

In November 2014, during nine days of scanning at Stable Pond, we sampled eight, $30 \mathrm{~m} \times 30 \mathrm{~m}$ plots, including the dried pond bed. The weather was cold (reaching a low of $-26^{\circ} \mathrm{C}$ ), with $12 \mathrm{~cm}$ of snow on the ground. We detected nine salamanders in six hibernation sites, 3-118 $\mathrm{m}$ from the edge of Stable Pond's highwater limit (Table 1). Detected sites were all in areas dominated by deciduous trees. As had been seen at Linnet Lake, one site was clearly associated with a stump, and two PIT-tagged individuals were detected there. The stump was not excavated, but salamanders appeared to be within the rotten wood matrix of the trunk and its roots at a depth of $\sim 36 \mathrm{~cm}$. The other five overwintering sites at Stable Pond were not obviously associated with specific aboveground objects, but logs and/ or large deciduous trees were present within $2 \mathrm{~m}$. These five sites were excavated, and two contained a second, untagged salamander. The seven salamanders were $28-38 \mathrm{~cm}$ below the ground surface within cavities left by decomposed roots $1.5-3 \mathrm{~cm}$ in diameter (likely Populus spp.). In all cases, the bark of the roots maintained their shapes even when no wood remained inside, thus creating tiny tunnels. One of the salamanders was one of 44 PIT-tagged YOY. Three of these salamanders had also been detected at Stable Pond during scanning in the summer at locations $10 \mathrm{~m}, 20 \mathrm{~m}$, and $168 \mathrm{~m}$ from their hibernation sites. Additional characteristics of Stable Pond sites are presented in Table 1.

\section{Discussion}

Overwintering macro- and micro-habitats are critical to northern terrestrial salamanders, as they spend a good portion of the year in these locations (Petranka 1998), which are vulnerable to natural and anthropogenic disturbances year-round. Knowledge of how far away from breeding ponds anurans and salamanders hiber- nate can help to establish conservation buffers to prevent unintended site degradation and destruction (Semlitsch and Bodie 2003). At our study sites in Waterton Lakes National Park, hibernacula of Long-toed Salamanders located using PIT telemetry were within $3 \mathrm{~m}$ and $168 \mathrm{~m}$ of breeding sites. Overwintering sites are likely much more distant for many individuals, especially those breeding in Linnet Lake. Using RFID antennas at openings for two of the four under-road tunnels, we detected $22 \%$ of 404 PIT-tagged salamanders in 2013 and $10 \%$ of 643 PIT-tagged salamanders in 2014 moving through these structures. These individuals would have travelled at least $200 \mathrm{~m}$ between their breeding lake and terrestrial habitat on the other side of Entrance Road.

What terrestrial macrohabitat features Long-toed Salamanders might have been seeking in crossing the road after breeding remains unclear. Vegetation cover surrounding hibernacula, for example, simply reflected the dominant plants growing around the breeding lake and pond. At a finer scale, Long-toed Salamanders in the vicinities of Linnet Lake and Stable Pond were found to overwinter in microhabitats created by the decomposing wood of tree stumps and their root systems. They also used tunnels at the interface of the decaying wood and the soil. The origin of these tunnels was unknown, but they may have been made by mammals or invertebrates. Monitoring of the under-road tunnels at Linnet Lake with cameras documented the presence of Deer Mice (Peromyscus maniculatus), shrews, voles, ground squirrels (Spermophilus spp.), chipmunks (Tamias spp.), and Red Squirrels at the site (Pagnucco 2010). The use by salamanders of burrows created by small mammals is well documented, including the use by Jefferson (Ambystoma jeffersonianum) and Spotted Salamanders (Ambystoma maculatum) of vertically oriented tunnels as overwintering sites (Madison 1997; Faccio 2003). Further north in Alberta's Aspen Parkland, Western Toads hibernate in below-ground tunnel systems linked to Red Squirrel cone middens (Browne and Paszkowski 2010) and Western Tiger Salamanders use Northern Pocket Gopher (Thomomys talpoides) burrows (Welsh 2016).

Inspection of three stumps that contained salamanders uncovered vertical tunnels within the soft, flakey wood that created spaces for salamanders to travel through and find shelter. Seven salamanders, located at five overwintering sites within poplar stands at Stable Pond, occupied similar passageways inside isolated complexes of hollow, rotten roots at depths $>25 \mathrm{~cm}$ that were not connected to stumps or living trunks (Table 1). Thus, various forms of standing, downed, and buried woody debris appear to offer appropriate hibernating conditions for Long-toed Salamanders at Waterton Lakes National Park, whether surrounded by grass, shrubs, or trees. Snow cover is likely very important in insulating these sites, as we estimated that the depth of the frost line at Waterton Lakes, based purely on freezing index degree-days, is $\sim 1400 \mathrm{~cm}$ (Urecon Ltd. 
2018). However, the park is one of the wettest areas in Alberta with an average annual total snowfall of $575 \mathrm{~cm}$ at the town site (Parks Canada 2017), which is $1.3 \mathrm{~km}$ from Linnet Lake; thus, hibernating salamanders at shallower soil depths are likely protected from freezing. We located salamanders at a narrow range of depths, $27-38 \mathrm{~cm}$. Our locations may not represent the true hibernation depths typical for these Long-toed Salamander populations, but instead reflect the limitations of PIT tag telemetry or the depths of temporary, earlyseason refugia from which animals eventually move deeper into the soil matrix.

Our findings share some aspects with Sheppard's (1977) observations for Long-toed Salamanders at a site $\sim 250 \mathrm{~km}$ northwest of Waterton in the Bow River valley. Sheppard found Long-toed Salamanders overwintering in refugia associated with the roots of trees. However, at his study site, it appeared that salamanders moved below ground through the loose gravel substrate rather than using tunnels or decomposing root systems. Ambystomatid species differ in their digging abilities, some being active excavators, while others are passive excavators that use their wedge-shaped heads to widen existing spaces in the substrata (Semlitsch 1983). It is generally assumed that Long-toed Salamander is a passive excavator, but this has not been definitively shown. At Sheppard's sites, the trees and roots associated with overwintering sites were living spruce, and he makes no mention of mammal burrows or any other possible points of entry to below-ground areas. Also, his sites were in a relatively flat area consisting of glacial deposits, which had high soil moisture levels. With one exception, the hibernacula in our study were substantially uphill from the aquatic breeding pond.

Like Sheppard, we found Long-toed Salamanders overwintering communally, as eight of the 13 salamanders $(61.5 \%)$ that we located occurred with a second individual. Sheppard found three juvenile salamanders overwintering with adults, and we also found one 12-year-old juvenile overwintering with an adult male, indicating that different age classes will share hibernacula. Juvenile Spotted Salamanders are attracted to burrows occupied by conspecifics, possibly an adaptation permitting naïve juveniles to find higher-quality refuges (Green et al. 2016). Long-toed Salamanders have been shown to express territorial behaviour, such as biting and avoidance (Ducey 1989); thus, the tolerance of conspecifics at hibernation sites that we observed may underscore the importance of these refuges and possibly their limited availability.

Despite the limitations of PIT-tag technology, such as low detection rates in rugged terrain or in dense vegetation and modest depth of detection, we were able to identify several salamander hibernacula in a relatively cost-effective manner (see also Ousterhout and Burkhart 2017). Our study has expanded knowledge of this poorly known, but important, aspect of the biology of Long-toed Salamander at the northeastern edge of its distribution. Over its geographic range, the species is viewed as adaptable, occurring in habitats as varied as sage-brush and alpine elevations over $2700 \mathrm{~m}$ (Graham and Powell 1999; Werner et al. 2004). With respect to hibernation sites, we found the species to be flexible in terms of vegetation cover, but consistently occurring in microhabitats provided by decaying wood at and below the soil surface.

The persistence of populations of Long-toed Salamanders in Waterton Lakes National Park and elsewhere in Alberta requires the conservation of structurally complex terrestrial habitat around breeding ponds to provide both foraging and overwintering sites. Our results are consistent with the recent provincial recommendation for the creation of 250-m buffers, featuring forest patches with downed woody debris, around Long-toed Salamander breeding ponds (Alberta Environment and Parks 2016). We recommend the preservation of standing dead tree trunks and stumps in forested buffers, even after disturbances such as logging, insect outbreaks, and wildfire, as a management action that will provide winter microhabitat for the species.

\section{Acknowledgements}

This study was funded in part by a National Sciences and Engineering Research Council Discovery grant to C.A.P. and grants from the Alberta Conservation Association, the Alberta Sport, Recreation, Parks and Wildlife Foundation Development Initiatives Program, and the Canadian Circumpolar Institute (Circumpolar/Boreal Alberta Research) to M.R.A.-A. The study was conducted under Parks Canada Agency Research and Collection permits WL-2012-13756 and EI-2013-13739 held by C.A.P. All procedures involving live amphibians were conducted with the approval of the University of Alberta Animal Care and Use Committee protocols AUP00000535 "Techniques for Marking and Tracking Amphibians" and AUP000005051 "Ecology and Behaviour of Ambystoma Salamanders" held by C.A.P. Logistic support was provided by Waterton Lakes National Park. Comments from three anonymous reviewers significantly improved this manuscript.

\section{Literature Cited}

Alberta Environment and Parks. 2014. Endangered, threatened, special concern and data deficient species in Alberta. Alberta Environment and Parks, Edmonton, Alberta, Canada. Accessed 30 October 2018. https://open.alberta.ca/data set/d5f03916-aa1a-4c37-acee-354e69a479f0/resource/7bc 9e468-740d-4f06-8805-212eb178ffa0/download/speciesat riskguide-aug27-2014.pdf.

Alberta Environment and Parks. 2016. Long-toed Salamander conservation management plan. Species at risk conservation management plan no.1. Alberta Environment and Parks, Edmonton, Alberta, Canada.

Atkinson-Adams, M.R. 2015. Movement and habitat use by long-toed salamanders (Ambystoma macrodactylum) in Waterton Lakes National Park, Alberta. M.Sc. thesis, University of Alberta, Edmonton, Alberta, Canada. 
Atkinson-Adams, M.R., C. Paszkowski, and G. Scrimgeour. 2016. Effects of substrate on PIT tag detection with a selfmade portable RFID antenna: implications for PIT telemetry. Herpetological Review 47: 198-201.

Barron, D.J., J.D. Brawn, and P.J. Weatherhead. 2010. Meta-analysis of transmitter effects on avian behavior and ecology. Methods in Ecology and Evolution 1: 180-187. https://doi.org/10.1111/j.2041-210X.2010.00013.x

Browne, C.L., and C.A. Paszkowski. 2010. Hibernation sites of western toads: characterization and management implications. Herpetological Conservation and Biology 5: 4963.

Connette, G.M., and R.D. Semlitsch. 2012. Successful use of a passive integrated transponder (PIT) system for belowground detection of plethodontid salamanders. Wildlife Research 39: 1-6. https://doi.org/10.1071/WR11055

Cucherousset, J., P. Marty, L. Pelozuelo, and J.-M. Roussel. 2008. Portable PIT detector as a new tool for non-disruptively locating individually tagged amphibians in the field: a case study with Pyrenean brook salamanders (Calotriton asper). Wildlife Research 35: 780-787. https://doi. org/10.1071/WR08074

Ducey, P.K. 1989. Agonistic behavior and biting during intraspecific encounters in Ambystoma salamanders. Herpetologica 45: 155-160.

Faccio, S.D. 2003. Postbreeding emigration and habitat use by Jefferson and Spotted salamanders in Vermont. Journal of Herpetology 37: 479-489. https://doi.org/10.1670/155-02A

Fukumoto, J., and S. Herrero. 1998. Observations of the long-toed salamander, Ambystoma macrodactylum, in Waterton Lakes National Park, Alberta. Accessed 2 October 2018. https://biodiversitylibrary.org/page/34257935. Canadian Field-Naturalist 112: 579-585.

Graham, K.G. 1997. Habitat use of Long-toed salamanders (Ambystoma macrodactylum) at three different scales. M.Sc. thesis, University of Guelph, Guelph, Ontario, Canada.

Graham, K.L., and G.L. Powell. 1999. Status of the Longtoed Salamander (Ambystoma macrodactylum) in Alberta. Wildlife status report 22. Alberta Environmental Protection, Fisheries and Wildlife Management Division, and Alberta Conservation Association, Edmonton, Alberta, Canada.

Greene, K.M., S.E. Pittman, and M.E. Dorcas. 2016. The effects of conspecifics on burrow selection in juvenile spotted salamanders (Ambystoma maculatum). Journal of Ethology 34: 309-314. https://doi.org/10.1007/s10164-0160476-6

Hamed, M.K., D.P. Ledford, and T.F. Laughlin. 2008. Monitoring non-breeding habitat activity by subterranean detection of Ambystomatid salamanders with implanted passive integrated transponder (PIT) tags and a radio frequency identification (RFID) antenna system. Herpetological Review 39: 303-306.

Kuhnz, L.A. 2000. Microhabitats and home range of the California legless lizard using biototelemtry. M.Sc. thesis, San Jose University, San Jose, California, USA.

Lee-Yaw, J.A., and D.E. Irwin. 2012. Large geographic range size reflects a patchwork of divergent lineages in the long-toed salamander (Ambystoma macrodactylum). Journal of Evolutionary Biology 25: 2276-2287. https://doi.org/ 10.1111/j.1420-9101.2012.02604.x

Madison, D.M. 1997. The emigration of radio-implanted spotted salamanders, Ambystoma maculatum. Journal of Herpetology 31: 542-551. https://doi.org/10.2307/1565607

Ott, J.A., and D.E. Scott. 1999. Effects of toe-clipping and PIT-tagging on growth and survival in metamorphic Ambystoma opacum. Journal of Herpetology 33: 344-348.
Ousterhout, B.H., and J.J. Burkhart. 2017. Moving beyond the plane: measuring 3D home ranges of juvenile salamanders with passive integrated transponder (PIT) tags. Behavioral Ecology and Sociobiology 71: 59. https://doi. org/10.1007/s00265-017-2284-6

Pagnucco, K.S. 2010. Using under-road tunnels to protect a declining population of long-toed salamanders (Ambystoma macrodactylum) in Waterton Lakes National Park. M.Sc. thesis, University of Alberta, Edmonton, Alberta, Canada.

Pagnucco, K.S., C.A. Paszkowski, and G.J. Scrimgeour. 2012. Characterizing movement patterns and spatio-temporal use of under-road tunnels by long-toed salamanders in Waterton Lakes National Park, Canada. Copeia 2012: 331340. https://doi.org/10.1643/CE-10-128

Parks Canada. 2017. Waterton Lakes National Park. Climate. Parks Canada, Ottawa, Ontario, Canada. Accessed 30 October 2018. https://www.pc.gc.ca/en/pn-np/ab/waterton/nature/ environment/climat-climate.

Pearson, K.J. 2004. The effects of introduced fish on the longtoed salamander (Ambystoma macrodactylum) in southwestern Alberta, Canada. M.Sc. thesis, University of Lethbridge, Lethbridge, Alberta, Canada.

Petranka, J.W. 1998. Salamanders of the United States and Canada. Smithsonian Institution Press, Washington, DC, USA.

Russell, A.P., and A.M. Bauer. 2000. The Reptiles and Amphibians of Alberta. University of Calgary Press, Calgary, Alberta, Canada.

Ryan, K.J., J.D. Zydlewski, and A.J.K. Calhoun. 2014. Using passive integrated transponder (PIT) systems for terrestrial detection of blue-spotted salamanders (Ambystoma laterale) in situ. Herpetology Conservation and Biology 9: 97-105.

Semlitsch, R.D. 1983. Burrowing ability and behavior of salamanders of the genus Ambystoma. Canadian Journal of Zoology 61: 616-620. https://doi.org/10.1139/z83-082

Semlitsch, R.D., and J.R. Bodie. 2003. Biological criteria for buffer zones around wetlands and riparian habitats for amphibians and reptiles. Conservation Biology 17: 12191228. https://doi.org/10.1046/j.1523-1739.2003.02177.x

Sheppard, R.F. 1977. The ecology and home range movements of Ambystoma macrodactylum krausii (Amphibia Urodela). M.Sc. thesis, University of Calgary, Calgary, Alberta, Canada.

Trenham, P.C., and B.H. Shaffer. 2005. Amphibian upland habitat use and its consequences for population viability. Ecological Applications 15: 1158-1168. https://doi.org/ 10.1890/04-1150

Urecon Ltd. 2018. Ambient temperatures - below ground. Urecon Ltd., Coteau-du-Lac, Quebec, Canada. Accessed 10 May 2018. http://www.urecon.com/applications/municipal ambient below.html.

Weatherhead, P.J., and G. Blouin-Demers. 2004. Long-term effects of radiotelemetry on black ratsnakes. Wildlife Society Bulletin 32: 900-906.

Welsh, K.J. 2016. Occupancy, abundance, and summer ecology of the Western Tiger Salamander (Ambystoma mavortium Baird) in the Beaver Hills, Alberta. M.Sc. thesis, University of Alberta, Edmonton, Alberta, Canada.

Werner, J.K., B.A. Maxwell, P. Hendricks, and D.L. Flath. 2004. Amphibians and Reptiles of Montana. Mountain Press Publishing Company, Missoula, Montana, USA.

Received 5 March 2018

Accepted 15 May 2018 